\title{
STATUTE OF THE GRAND DUCHY OF LITHUANIA ${ }^{1}$
}

\section{Abstract:}

The article is devoted to the history of creation and publication of the Statute of the Grand Duchy of Lithuania in 1588. The Statute of 1588 was the main body of civil laws of the Grand Duchy of Lithuania, Russia and Samogitia: one of the largest state entities in Europe of its time. The Statute of 1588 was in force until the beginning of the 19th century and became the most famous title of the 5,000 books published in the Grand Duchy of Lithuania in its history.

Keywords:

Statutes of the Grand Duchy of Lithuania, Belarusian literature, the East Slavic book culture, Slavic studies.

АнНОтация: Ю.А. ЛАБЫнцЕВ. «СТАТУТ ВЕЛИКОГО КняЖЕСТВА ЛиТОВСКОГО».

Статья посвящена истории создания и издания Cmaтута Великого княжества Литовского 1588 г. Статут 1588 г. был основным сводом гражданских законов Великого княжества Литовского, Русского и Жемойтского - одного из крупнейших государственных образований в Европе своего времени. Статут 1588 г. действовал вплоть до начала ХІХ в. и стал самым известным изданием из 5000 книг, изданных в Великом княжестве Литовском за всю его историю.

\section{Ключевые слова:}

Статуты Великого княжества Литовского, Великое княжество Литовское, белорусская литература, восточнославянская книжность, славистика.

7 the Statute of the Grand Duchy of Lithuania of 1588 is the main set of civil laws in force on the territory of the Grand Duchy of Lithuania, Russia and Samogitia. It served as a "constitution" of the power that was once one of the largest in Europe and a kind of guarantor of its independence. The "Statute" is a legal and literary monument, which has incorporated all the best from the very rich Cyril and Methodius heritage of this East European state. The Statute of the Grand Duchy of Lithuania of 1588 has always been considered not only as a symbol of the independence of this state, inhabited mostly by Eastern Slavs, but also as an object of special national pride for Belarusians, Lithuanians and, in part, Ukrainians. It is an exceptional monument, very important for the history of the Old Belarusian language and literature, created over decades by the best minds of the Belarusian people, and then for centuries contributed to the preservation of the native culture.

1 The work was carried out with the financial support of the RFBR (grant № 18-512-76004). 
The first Statute of the Grand Duchy of Lithuania, containing the norms of land, criminal, civil, procedural and state law, was drawn up in 1529 and consisted of 13 sections. Since it included many outdated provisions, it became necessary to make corrections and changes to it. In 1566 a new version of the "Statute" was composed, consisting of 14 sections. The third Lithuanian "Statute" saw the light of day in the famous printing house of the Vilnius merchants, the Mamoniches, in 1588. All three statutes were the fruit of painstaking work of many authors, a kind of collective essay that over the years was written, corrected, edited. The leading role in the preparation of each was assigned to a special commission, which consisted of various specialists. The commission for the drafting of the Statute of 1588, appointed by the King, consisted of eleven people, among whom were Orthodox as well as Catholics and Protestants. The center of the commission's activity was the state chancellery, headed by chancellors and sub-chancellors. Its record-keeping was then conducted in the West Russian language with elements of the Old Belarusian and Old Ukrainian dialects. A special role in the preparation of the draft of the Statute of 1588 was played by Chancellor Ostafy Volovich, who converted from Calvinism to Ortho-

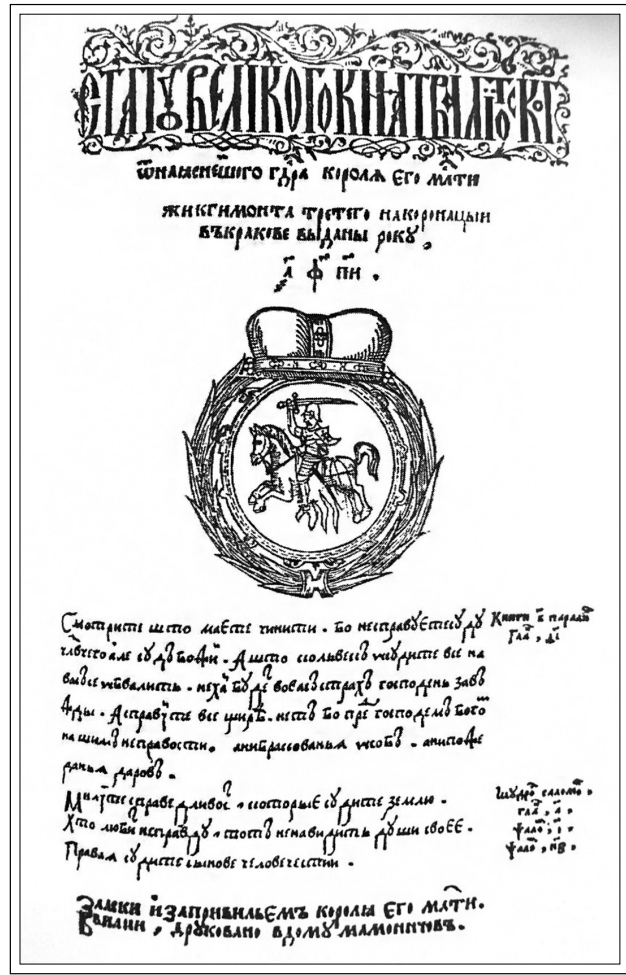

The title page of the first edition of the Statute of the Grand Duchy of Lithuania, 1588 doxy, and sub-Chancellor Leo Sapega, who became a Catholic in these years. They knew the local literary language of that time perfectly, and the priority of the Old Belarusian elements in it was then undeniable: this was reflected in many provisions of the 1588 Statute enshrining its state character. There are known to have been three separate editions of the text of the Lithuanian Statute with a publication date of 1588 ; they differ, in particular, in the design of the title page and its turnover. The sole right to publish the statute in Latin (Polish) and Cyrillic ("Russian") fonts was granted by the King to Leo Sapega, which he used until his death in 1633. The original monument, including its list, approved by the King, was written in West Russian language, which included elements of the Old Belarusian and Old Ukrainian dialects. The Polish translation appeared much later, and its quality was not entirely satisfactory, since the Polish terminology of that time could not reflect all the features 
of the material and spiritual life of the population of the Grand Duchy of Lithuania. The first Polish-language edition of the statute was printed in the very same Mamonich printing house only in 1614, and the second in 1619.

Scholars initially considered the Lithuanian statutes exclusively as monuments of the history of law, but as they were studied, they began to be perceived as monuments of written culture. This was especially true of the Statute of 1588 , which had a significant impact on the cultural destinies of neighboring peoples. It was repeatedly reprinted, sold in many thousands of copies, and for more than three centuries served to preserve and develop the Old Belarusian language and literature and to confirm their significance.

The Statute of 1588 was the principal and most important publication among the five thousand books published in the Grand Duchy of Lithuania before the beginning of the 19th century. Also, like the works of Francisk Skorina,

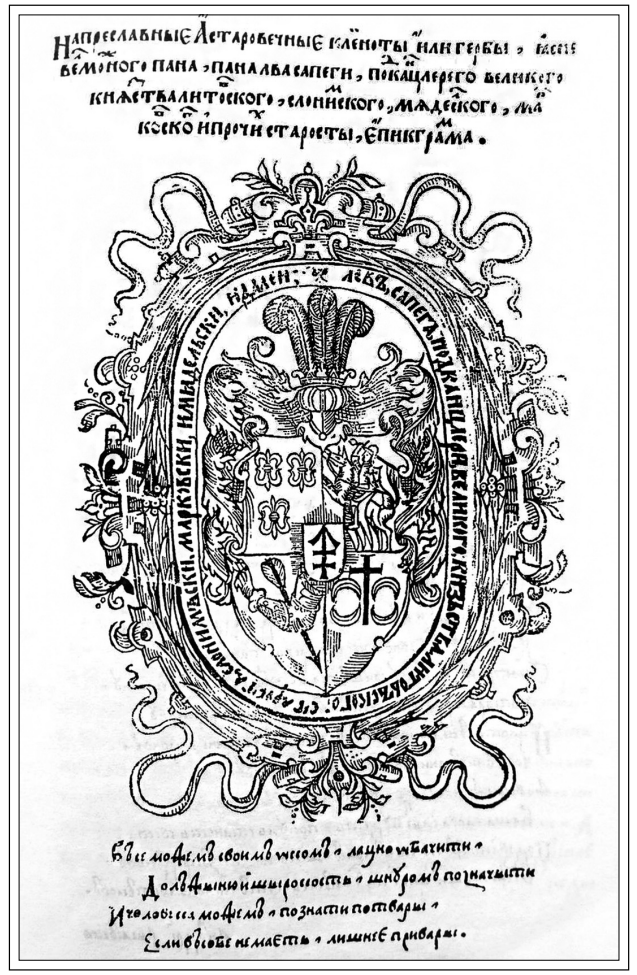

The coat of arms of Leo Sapega in the first edition of the Statute of the Grand Duchy of Lithuania,

1588 this document of Old Belarusian literature aroused great interest in the newly emerging field of Slavic studies at the beginning of the 19th century. All three editions of the 1588 Statute, with a combined circulation of about 4,000 copies, were widely distributed in the state and far beyond its borders. It was in use until the first half of the 19th century, and legal proceedings based on it were still being conducted in some places as late as the 19th century, as evidenced by marks on surviving specimens. Several dozen handwritten copies of the Statute of 1588 are also known. Many countries worldwide evinced a great deal of interest in this publication. Over time a large number of copies appeared in the book collections of famous cultural figures, including Russians. The Statute of 1588 remains to this day the most important evidence of the greatness of what was once one of the most powerful states in Europe. 


\section{BIBLIOGRAPHY}

Lappo II. Litovskij Statut 1588 g. Kaunas, 1934-1938. T. 1-2.

Statut Vialikaha kniastva Litouskaha 1588 hoda: Teksty. Davied. Kamient / Bielarus.

Sav. Encykl.; redkal.: I. P. Šamiakin (hal. red.) [i inš.]. - Minsk, 1989. 573 S.

Makišev $V$. Kirilličeskie izdania Litovskogo Statuta 1588 goda. Krakov, 2014

\section{ILLUSTRATIONS}

1. The title page of the first edition of the Statute of the Grand Duchy of Lithuania, 1588.

2. The title page of the second edition of the Statute of the Grand Duchy of Lithuania, 1588.

3. The title page of the third edition of the Statute of the Grand Duchy of Lithuania, 1588.

4. The coat of arms of Leo Sapega in the first edition of the Statute of the Grand Duchy of Lithuania, 1588.

5. Portrait of King Sigismund III Vasa in the second edition of the Statute of the Grand Duchy of Lithuania, 1588.

6. Portrait of King Sigismund III Vasa in the third edition of the Statute of the Grand Duchy of Lithuania, 1588.

7. Appeal of Lev Sapega to the population of the country in the first edition of the Statute of the Grand Duchy of Lithuania, 1588.

8. The privilege of King Sigismund III Vasa to publish in the first edition of the Statute of the Grand Duchy of Lithuania, 1588.

9. The privilege of King Sigismund III Vasa to publish in the second edition of the Statute of the Grand Duchy of Lithuania, 1588.

10. The title page of the second Polish-language edition of the Statute of the Grand Duchy of Lithuania of 1588. Wilno, 1619. 